\title{
The influence of foliar treatment on the quality of table grape during storage
}

\author{
Svetlana Levchenko, Sofia Cherviak", Vladimir Boyko, Dmitriy Belash, and Alexander \\ Romanov \\ All-Russian National Research Institute of Viniculture and Winemaking "Magarach" of RAS, Kirova \\ Str, 31, Yalta, 298600, Republic of Crimea, Russian Federation
}

\begin{abstract}
One of the main factors increasing the productivity of vineyards and the quality of fresh grapes during storage is the use of vegetative treatments with bioregulators of various physiological effects. This work is devoted to the study and comparative assessment of various foliar treatments with the growth regulator "Albit", "Glycerol" and a complex of fertilizers LLC "Biochefarm Rus" on agro biological and commercial quality characteristics of the table grape variety 'Moldova' during the longterm storage. Foliar treatments were carried out in the main phases of the growing season: 'before flowering', 'after flowering', 'the beginning of growth', 'the beginning of ripening'. Sampling for analyzes was carried out for 30,90 and 150 days of storage. It was found that foliar treatment leading to a significant increase in cropping capacity of grapes by $26.8 \%$ ("Biochefarm"), 36.5\% ("Albit") and 20.0\% ("Glycerol"). The increase in the average weight of the bunch in the experimental variants grew by 29.6 $31.3 \%$. The use of experimental schemes of foliar treatments made it possible to increase the keeping quality of table grapes: the weight loss of bunch decreased by $0.3-3.5 \%$. The tasting assessment of the experimental batches of grapes at the end of storage exceeded the control by $5.6-6.9 \%$.
\end{abstract}

\section{Introduction}

Grapes are the product which is characterized by valuable nutritional, taste and dietary properties. The grape berry has accumulated more than 800 components that determine its taste and aroma, such as vitamins, organic and amino acids, mineral, pectin and aromatic substances; however, it can be consumed fresh only for a significantly limited time [1-3]. It is possible to provide customers with fresh grapes for a longer period by ensuring its longterm storage. At the same time, the most important thing is to preserve the appearance, high commercial qualities and nutritional value of grape berries [4-7].

The effectiveness of long-term storage of grapes and the reduction of losses caused by phytopathological and physiological diseases depends on many factors, and the varietal characteristics, agro technical methods of cultivation, temperature and humidity regime are the most important of them. During long-term storage of grapes, it is necessary to take into

\footnotetext{
*Corresponding author: $\underline{\text { Sofi4@ } @ \text { list.ru }}$
} 
account the speed of physiological and biochemical processes occurring in berries, and their dynamics depending on endogenous and exogenous factors.

The analysis of the state of viniculture shows that one of the weakest links in the technological chain of production of table grapes is its storage; therefore, the research into the ways to provide the general population with fresh produce is an important task.

One of the main factors of increasing the productivity of grape plantations and the quality of fresh grapes during its storage is the use of vegetation treatments with bio regulators which have various physiological effects [7-9]. The effect of bio regulators on the leaf surface at the cellular structures levels boosts the grape's productivity and increases the bunch weight, and in general, it is an improvement of uvology characteristics.

Previous studies show a positive effect of bio regulators in foliar fertilizing on the productivity and yield quality of grape cultivars [10]. Thus, the yield increased by $20.6 \%$ for 'Moldova' and by $22.4 \%$ for 'Asma' clvs due to the increased weight of the bunch. Total sugars increased by $6.7-11.4 \%$ as compared to control. The use of foliar fertilizing improved the organoleptic characteristics of the grapes by $5.1-6.2 \%$.

The aim of these studies is to analyze and compare the impact of various foliar treatments with growth regulators Albit, Glycerol and a fertilizer complex of LLC "Biochefarm Rus Ltd" ("Seamino Pro", "Double Win", "Boro Pro") on agro biological indicators and characteristics of commercial quality of table grapes during the long-term storage. The compositions and characteristics of the investigated preparations are presented in Table 1.

Table 1. Characteristics of the preparations

\begin{tabular}{|c|l|}
\hline $\begin{array}{c}\text { Name of } \\
\text { preparation }\end{array}$ & \multicolumn{1}{c|}{ Main characteristics } \\
\hline Albit & $\begin{array}{l}\text { a growth regulator, the active substance of which is a natural biopolymer poly-beta- } \\
\text { hydroxybutyric acid from the soil bacteria Bacillus Megaterium. The mechanism of } \\
\text { action of Albite is based on stimulating the protective reactions of the plant and } \\
\text { increasing resistance to pesticide stress, drought, extreme temperatures, frost, } \\
\text { chemical contamination of soils, salinization and other stresses, as well as to a wide } \\
\text { range of pathogens. }\end{array}$ \\
\hline Biochefarm & $\begin{array}{l}\text { The basis of the preparations is seaweed extracts containing non-nitrogen organic } \\
\text { substances, vitamins, amino acids and trace elements (iron, copper, zinc, } \\
\text { magnesium, etc.). It promotes the stimulation of internal factors of vital activity and } \\
\text { regulates the balance of endogenous hormones. }\end{array}$ \\
\hline Glycerol & $\begin{array}{l}\text { a complex of fertilizers, which, in addition to nutrients, includes glycerin, whose } \\
\text { derivatives, triglycerides are important components of metabolism. The glycerol } \\
\text { derivatives, which are contained in the fertilizer (mono - and diglycerides), ensure } \\
\text { the formation of a stable film on the plants leaves, which prevents the premature } \\
\text { release of moisture from the green mass. }\end{array}$ \\
\hline
\end{tabular}

\section{Materials and methods}

The object of the study was the table grape variety Moldova (the culture does not require covering, the planting scheme was $3.0 \times 1.5 \mathrm{~m}$ ), as the most common variety in the vineyards of Crimea. The research methodology included 3 experimental nutrition systems (the use of the studied preparations) and a control one (Table 2). The control was the production technology of grape cultivation on the commercial vineyard.

Experimental studies were carried out during 2017-2020 on 'Moldova' grape variety, cultivated in mountain-valley zone of viticulture of the Republic of Crimea (Morskoye branch of PJSC Massandra) and in the department of storage and processing of grapes, fruit and vegetable products of the Institute Magarach. 
In order to assess the agricultural background of the experimental plots and to establish the actual fruitfulness (differentiation of inflorescences), the following agrobiological indicators of grapes were studied, such as estimating the number of buds, developed shoots, fruiting shoots, inflorescences, bunches, average bunch weight and plant yield $(\mathrm{kg})$ for each genotype.

The indicators of commercial quality of grapes were determined according to the following criteria: cropping capacity, harvest from a bush; average mass of a bunch; yield of standard products; mass concentration of sugars and titratable acids, as well as tasting assessment by the sensory analysis on a ten-point scale $[11,12]$. Mathematical processing of experimental data was carried out in the Microsoft Excel program. In order to determine the natural weight loss, batches of 5 boxes were formed; each of them containing 4 bunches of grapes which were packed in a polymer mesh with a cell diameter of $0.5 \mathrm{~cm}$.

Table 2. Scheme of foliar top dressing of table grapes

\begin{tabular}{|c|c|c|}
\hline Preparation Biochefarm & Preparation Glycerol & Preparation Albit \\
\hline \multicolumn{3}{|c|}{ The vegetation phase - before flowering } \\
\hline $\begin{array}{c}\text { Seamino Pro } 21 / \mathrm{ha} \\
\text { Double Win } 3: 11: 382 \mathrm{~kg} / \mathrm{ha} \\
\text { Boro Pro } 1 \mathrm{1} / \mathrm{ha} \\
\text { Soft Guard } 0.5 \mathrm{l} / \mathrm{ha}\end{array}$ & $\begin{array}{l}\text { Boron } 400 \text { 1/ha } \\
\text { Complex 1/ha }\end{array}$ & $0.2 \mathrm{l} / \mathrm{ha}$ \\
\hline \multicolumn{3}{|c|}{ The vegetation phase - after flowering } \\
\hline $\begin{array}{c}\text { Seamino Pro } 2 \mathrm{l} / \mathrm{ha} \\
\text { Double Win } 18: 18: 1 \mathrm{~kg} / \mathrm{ha} \\
\text { Boro Pro } 0.51 / \mathrm{ha} \\
\text { Algae } 0.5 \mathrm{~kg} / \mathrm{ha}\end{array}$ & $\begin{array}{l}\text { Boron } 4001 / \text { ha } \\
\text { Zink } 1 / \text { ha } \\
\text { Complex } 1 / \text { ha }\end{array}$ & $0.2 \mathrm{l} / \mathrm{ha}$ \\
\hline \multicolumn{3}{|c|}{ The vegetation phase - the beginning of berry growth } \\
\hline $\begin{array}{c}\text { Double Win } 13 ; 11 ; 382 \mathrm{~kg} / \mathrm{ha} \\
\text { Master Green Ca } 11 / \mathrm{ha} \\
\text { Seamino Pro } 11 / \mathrm{ha}\end{array}$ & $\begin{array}{l}\text { Boron } 400 \text { 1/ha } \\
\text { Complex 1/ha }\end{array}$ & $0.2 \mathrm{l} / \mathrm{ha}$ \\
\hline \multicolumn{3}{|c|}{ The vegetation phase - the beginning of berry ripening } \\
\hline $\begin{array}{l}\text { Master Green Ca } 0.5 \text { 1/ha } \\
\text { Seamino Pro } 11 / \mathrm{ha} \\
\text { Soft Guard } 11 / \mathrm{ha} \\
\end{array}$ & $\begin{array}{l}\text { Complex 1/ha } \\
\text { Zink 1/ha }\end{array}$ & $0.2 \mathrm{l} / \mathrm{ha}$ \\
\hline
\end{tabular}

Fresh grapes were stored in an industrial refrigerator at a temperature of $0 \pm 2{ }^{\circ} \mathrm{C}$ and a relative humidity of $90-95 \%$ for 150 days with regular treatment with sulfur dioxide. Sampling was carried out after 30,90 and 150 days. The studies were conducted in a fourfold repetition in each variant of the experiment.

The effectiveness of the studied treatment systems was evaluated by the dynamics of changes in the conditioned indicators of grapes: the mass concentration of sugars and titratable acids, the activity of polyphenol oxidase (PPO), the value of the natural loss of bunch weight (NLW), as well as the tasting assessment.

\section{Results and Discussion}

The assessment of the agricultural background of the experimental plots and the establishment of the actual fruitfulness (differentiation of inflorescences) indicates that the experiments were performed under the conditions of a leveled agro biological background, with equal loads of bushes, with a minimal difference between developed and fruiting shoots (Table 3 ).

As a result of the conducted studies, the influence of foliar top dressing with growthstimulating effect, caused by the preparations of various physiological effects, as an 
element of the cultivation technology of table grapes, on the actual cropping capacity and yield of standard products of the studied varieties which were evaluated.

Table 3. Assessment of the agro biological background of experimental plots

\begin{tabular}{|c|c|c|c|c|c|c|c|c|}
\hline \multirow{2}{*}{ Variant } & \multirow{2}{*}{$\begin{array}{c}\text { Bush } \\
\text { load, hl. }\end{array}$} & \multicolumn{2}{|c|}{$\begin{array}{l}\text { Developed shoots } \\
\text { on the bush }\end{array}$} & \multicolumn{2}{|c|}{$\begin{array}{c}\text { Fruiting } \\
\text { shoots }\end{array}$} & \multirow{2}{*}{$\begin{array}{l}\text { Number of } \\
\text { inflorescences } \\
\text { pc. }\end{array}$} & \multicolumn{2}{|c|}{ Rates* } \\
\hline & & pc. & $\%$ & pc. & $\%$ & & $K_{1}$ & $K_{2}$ \\
\hline Control & 24.1 & 19.2 & 79.7 & 17.0 & 70.5 & 18.2 & 0.95 & 1.07 \\
\hline Albit & 24.0 & 18.7 & 77.9 & 16.8 & 70.0 & 17.6 & 0.94 & 1.05 \\
\hline Control & 24.2 & 17.9 & 74.0 & 12.3 & 68.7 & 14.2 & 0.79 & 1.15 \\
\hline Glycerol & 24.0 & 18.1 & 75.4 & 12.4 & 68.5 & 14.4 & 0.80 & 1.16 \\
\hline Control & 24.2 & 17.9 & 74.0 & 12.3 & 68.7 & 14.2 & 0.79 & 1.15 \\
\hline Biochefarm & 23.8 & 17.8 & 74.8 & 13.6 & 76.4 & 15.8 & 0.89 & 1.16 \\
\hline
\end{tabular}

$* \mathrm{~K}_{1}$ - fruiting rate, $\mathrm{K}_{2}$ - fruitfulness rate.

A positive change in uvological indicators due to foliar fertilization contributed to a significant increase in grape yield (Table 4). According to the increase of this indicator, the studied preparations can be arranged in the following sequence: Glycerol $(20.0 \%) \rightarrow$ Biochefarm (26.8\%) $\rightarrow$ Albit (36.5\%). Mathematical processing of data showed that the influence of the studied preparations on the yield and quality of grapes was significant (Student's t-test $<0.05$ ).

Table 4. Evaluation of the cropping capacity and quality of table grapes

\begin{tabular}{|c|c|c|c|c|c|c|}
\hline \multirow[b]{2}{*}{ Variant } & \multicolumn{2}{|c|}{ Average weight, $\mathrm{kg}$} & \multirow[b]{2}{*}{$\begin{array}{c}\text { Cropping } \\
\text { capacity, } \\
\text { t/ ha }\end{array}$} & \multirow[b]{2}{*}{$\begin{array}{c}\text { Standard } \\
\text { product } \\
\text { output, \% }\end{array}$} & \multicolumn{2}{|c|}{ Mass concentration, $\mathrm{g} / \mathrm{l}$} \\
\hline & $\begin{array}{c}\text { of a } \\
\text { bunch of } \\
\text { grapes }\end{array}$ & $\begin{array}{l}\text { of the } \\
\text { yield from } \\
\text { a bush }\end{array}$ & & & sugars & $\begin{array}{l}\text { titratable } \\
\text { acids }\end{array}$ \\
\hline Control & 0.27 & 7.10 & 13.68 & 94.7 & 208 & 6.10 \\
\hline Albit & 0.35 & 7.90 & 18.67 & 95.3 & 209 & 6.10 \\
\hline $\begin{array}{c}\text { Student's t-test } \\
\text { (for paired samples) }\end{array}$ & 0.02 & 0.07 & 0.04 & 0.3 & 0.48 & 0.90 \\
\hline Control & 0.33 & 5.20 & 11.71 & 87.4 & 173 & 7.60 \\
\hline Glycerol & 0.42 & 6.70 & 14.05 & 90.5 & 189 & 6.60 \\
\hline $\begin{array}{c}\text { Student's t-test } \\
\text { (for paired samples) }\end{array}$ & 0.02 & 0.005 & 0.02 & 0.003 & 0.004 & 0.001 \\
\hline Control & 0.32 & 7.70 & 17.08 & 94.3 & 182 & 6.10 \\
\hline Biochefarm & 0.42 & 9.90 & 21.65 & 95.5 & 227 & 5.80 \\
\hline $\begin{array}{c}\text { Student's t-test } \\
\text { (for paired samples) }\end{array}$ & 0.01 & 0.002 & 0.004 & 0.4 & 0.0007 & 0.2 \\
\hline
\end{tabular}

In general, the cropping capacity increased with all experimental schemes of fertilization, which was due to enlargement of the average size of berries and bunches. The average mass of a bunch in the control variants varied in the range of $0.27-0.33 \mathrm{~kg}$, while in the experimental variants the value of the indicator increased by $29.6-31.3 \%$ and it was $0.35-0.42 \mathrm{~kg}$. The maximum increase in the average mass of the bunch was noted in the variant of the experiment with the use of foliar top dressing with Biochefarm preparations.

Along with an enlargement of cropping capacity while using foliar fertilizing, an increase in the yield of standard products of the studied grape varieties was noted - by 0.6$3.1 \%$ compared to control samples.

The evaluation of the grapes' physical and chemical parameters indicates a positive 
effect of the studied nutrition schemes on the quality indicators of raw materials. With the use of Glycerol and Biochepharm preparations, it was noted an increase in the mass concentration of sugars (by 16 and $45 \mathrm{~g} / \mathrm{l}$, respectively) with a slight decrease in the content of titratable acids, which indicates an earlier achievement of maturity. Treatment with Albit did not affect the quantitative content of sugars and titratable acids

The next stage of the study included an assessment of the quality indicators of experimental and control samples of grapes (Table. 5) in the dynamics of long-term storage (using Biochefarm and Albit preparations).

Table 5. Changes in the physico-chemical parameters of the table grape variety Moldova during the long-term storage

\begin{tabular}{|c|c|c|c|c|c|c|c|c|c|c|c|c|c|}
\hline \multirow{3}{*}{ variants } & \multirow{3}{*}{$\begin{array}{l}\text { Period } \\
\text { of } \\
\text { storage }\end{array}$} & \multicolumn{4}{|c|}{$\begin{array}{c}\text { Mass concentration, } \\
\text { g/1 }\end{array}$} & \multirow{2}{*}{\multicolumn{2}{|c|}{$\begin{array}{c}\text { Polyphenol } \\
\text { oxidase, mmol } \\
\text { min. }\end{array}$}} & \multirow{2}{*}{\multicolumn{2}{|c|}{$\begin{array}{l}\text { Respiration rate } \\
\mathrm{mg} \mathrm{CO}_{2} / \mathrm{kg}^{*} \mathrm{~h}\end{array}$}} & \multirow{2}{*}{\multicolumn{2}{|c|}{$\begin{array}{c}\text { Tasting } \\
\text { assessment, } \\
\text { point } \\
\end{array}$}} & \multirow{2}{*}{\multicolumn{2}{|c|}{ NLW, \% }} \\
\hline & & \multicolumn{2}{|c|}{ sugars } & \multicolumn{2}{|c|}{ sugars } & & & & & & & & \\
\hline & & $\mathrm{B}^{*}$ & $A^{* *}$ & B & A & B & A & B & A & B & A & B & A \\
\hline \multirow{4}{*}{ control } & 0 & 182 & 208 & 6.1 & 6.1 & 0.0224 & 0.0202 & 11.1 & 5.8 & 7.6 & 8.2 & - & - \\
\hline & 30 & 196 & 218 & 5.9 & 5.7 & 0.0013 & 0.0014 & 14.0 & 6.8 & 7.7 & 7.4 & 3.4 & 2.3 \\
\hline & 90 & 196 & 226 & 5.4 & 5.6 & 0.0012 & 0.0012 & 16.5 & 9.3 & 5.4 & 8.2 & 6.7 & 5.8 \\
\hline & 150 & 180 & 196 & 6.5 & 5.6 & 0.0021 & 0.0015 & 18.1 & 12.0 & 7.3 & 6.5 & 8.9 & 7.9 \\
\hline \multirow{4}{*}{ experience } & 0 & 227 & 209 & 5.8 & 6.1 & 0.0228 & 0.0186 & 12.1 & 5.4 & 8.9 & 9.2 & - & - \\
\hline & 30 & 223 & 215 & 6.0 & 6.4 & 0.0014 & 0.0014 & 13.0 & 6.0 & 8.9 & 8.6 & 1.6 & 1.8 \\
\hline & 90 & 220 & 220 & 5.4 & 5.9 & 0.0012 & 0.0013 & 15.2 & 8.6 & 7.5 & 8.9 & 4.9 & 2.3 \\
\hline & 150 & 226 & 218 & 5.5 & 6.5 & 0.0023 & 0.0032 & 17.8 & 10.5 & 7.8 & 6.9 & 8.6 & 6.9 \\
\hline
\end{tabular}

* B - Biochefarm, **A - Albit

The most important respiratory material includes carbohydrates, as well as organic acids as highly oxidized respiratory substrates. During storage, there was a gradual increase in the intensity of breathing, regardless of the experience variant.

Thus, the process of grapes' respiration during storage through the consumption of plastic substances is directly related to the indicator of natural loss of mass. The maximum mass loss was noted in the control variants during the entire storage period. The use of the studied nutrition schemes helped to reduce the natural loss of bunch weight: by $0.5-1.8 \%$ during 30 days of storage, 1.8-3.5 \% - 90 days and 0.3-1.0\% - after 150 days. A similar pattern is observed for grape samples with an experimental Glycerol nutrition system.

When analyzing the obtained data on the activity of redox enzymes in the storage process, the following regularities were established: the activity of polyphenol oxidase is maximum in fresh grapes, there is a sharp decrease in activity by 30 and 90 days of storage. With further storage by 150 days, a slight increase in activity is noted in all variants of the experiment. It was also noted that a decrease in the activity of oxidative enzymes had a positive effect on the quality of table grapes and contributed to a better preservation.

During storage, a uniform decrease in the organoleptic indicators of the studied grape varieties was noted in all variants of the experiment. However, the higher assessments of organoleptic indicators when storing grapes contributed to a significant superiority of the experimental samples over the control ones throughout the entire period of the study: Biochefarm - by $6.9 \%$, Albit - by $6.1 \%$, Glycerol - by $5.6 \%$. It was found that the 
experimental samples of grapes were characterized by higher values of the tasting assessment relative to the control during the entire period of storage. Analysis of the tasting assessment of table grapes in the dynamics of post-harvest storage showed that the use of investigated preparations gives a positive effect on organoleptic indicators of the studied grape samples, as well as the establishment of this indicator in the dynamics of grapes storage.

During the research, it was proved that the use of the investigated preparations contributes to a significant increase in yield and an increase in the quality indicators of the Moldova grape variety. Getting a better harvest when using foliar dressing contributes to better preservation of grapes during long-term storage.

\section{Conclusions}

As a result of the conducted research, it was found that the use of foliar nutrition systems (in case of foliar fertilizing with preparations Albit, Biochefarm and Glycerol) during the growing season of grape plant had a positive effect on agrotechnical practice for obtaining a high-quality yield of table varieties and for increasing of their keeping capacity: respiratory processes are inhibited and because of that the natural loss of the mass of the bunch is reduced.

The increase in the average weight of the bunch in the experimental variants grew by 29.6-31.3\%. The effectiveness of the use of foliar treatments on the yield of grapes is shown - according to the increase in the growth of the indicator, the studied preparations are arranged in the following sequence: Glycerol $(20.0 \%) \rightarrow$ Biochefarm $(26.8 \%) \rightarrow$ Albit $(36.5 \%)$. The increase in the yield of standard production of the studied grape varieties was $0.6-3.1 \%$ in relation to the control options.

The use of the studied feeding schemes aided to reduce the natural loss of bunch weight by $0.3-3.5 \%$ during long-term storage and contributed to a better preservation of marketable quality (by 5.6-6.9\%) compared to the control.

\section{References}

1. P. Kandylis, Foods, 10, 672 (2021)

2. C.Di Lorenzo, F. Colombo, E. Sangiovanni et al., BIO Web of Conferences 15, 04005 (2019)

3. A. Seccia, R. Viscecchia, and G. Nardone, BIO Web of Conferences 15, 03011 (2019)

4. S. Chironi, G. Sortino, A. Allegra, F. Saletta, V. Caviglia, M. Ingrassia, Chemical Engineering Transactions, 58, 421-426 (2017)

5. S. Cherviak, S. Levchenko, V. Boyko, D. Belash, E3S Web of Conferences 232, 03023 (2021)

6. E. Feliziani et al., Postharvest Biology and Technology 93, 38-48 (2014)

7. F.K. Sabir, A. Sabir, S. Unal, M. Taytak, A. Kucukbasmaci, O.F. Bilgin, International journal of fruit science 19 (4), 347-358 (2019)

8. S.V. Levchenko, S.N. Cherviak, V.A. Boiko, D.Yu. Belash, E.V. Ostroukhova, N.Yu. Lutkova, E3S Web of Conferences 232, 03026 (2021)

9. A. Batukaev, S. Levchenko, E. Ostroukhova, V. Boiko, I. Peskova, P. Probeygolova, D. Belash, N. Lutkova, BIO Web of Conferences 15, 01012 (2019)

10. S. Levchenko, V. Boyko, D.Belash, E. Lanina, Magarach. Viticulture and vinemaking. 2, 13-15 (2017) 
11. D. Belash, V. Boiko, Magarach. Viticulture and Winemaking 20, 9 (2018) (in Russian)

12. Compendium of international methods of wine and must analysis (International organization of vine and wine, Paris, 2017) 